\title{
Configurações
}

Revista de sociologia

\section{Richard Hindmarsh e Barbara Prainsack (eds.), Genetic Suspects: Global governance of forensic DNA profiling and databasing}

\section{Filipe Santos}

\author{
(2) OpenEdition \\ Journals \\ Edição electrónica \\ URL: http://journals.openedition.org/configuracoes/879 \\ DOI: $10.4000 /$ configuracoes.879 \\ ISSN: 2182-7419 \\ Editora \\ Centro de Investigação em Ciências Sociais \\ Edição impressa \\ Data de publição: 5 fevereiro 2011 \\ Paginação: 175-178 \\ ISSN: 1646-5075 \\ Refêrencia eletrónica \\ Filipe Santos, «Richard Hindmarsh e Barbara Prainsack (eds.), Genetic Suspects: Global governance \\ of forensic DNA profiling and databasing », Configurações [Online], 8 | 2011, posto online no dia 21 \\ fevereiro 2013, consultado o 22 setembro 2020. URL : http://journals.openedition.org/configuracoes/ \\ 879 ; DOI : https://doi.org/10.4000/configuracoes.879
}

Este documento foi criado de forma automática no dia 22 setembro 2020.

(c) CICS 


\title{
Richard Hindmarsh e Barbara Prainsack (eds.), Genetic Suspects: Global governance of forensic DNA profiling and databasing
}

\author{
Filipe Santos
}

\section{REFERÊNCIA}

Richard Hindmarsh e Barbara Prainsack (eds.), Genetic Suspects: Global governance of forensic DNA profiling and databasing

1 Richard Hindmarsh é Professor Associado no Centre for Governance and Public Policy, Griffi th University, e na Griffi th School of Environment, em Brisbane, Austrália. Tem desempenhado um papel fundamental nos estudos acerca das relações entre sociedade e biotecnologia, sendo responsável por várias antologias e números especiais de revistas científi cas dedicados às novas questões da genética, tais como a New Genetics and Society e a Science as Culture. Barbara Prainsack é diretora-adjunta do Centre for Biomedicine \& Society (CBAS) no Reino Unido. Anteriormente, fez parte do Department of Political Science and the Life Science Governance Platform da Universidade de Viena, Áustria. Os dois autores deste volume participaram no projecto de investigação internacional Genes without Borders - Towards global genomic governance (2006-2008), do qual resultou a obra em análise.

2 Este projecto envolveu a colaboração de diversos investigadores de vários países e partiu do questionamento fundamental da governância das novas tecnologias e aplicações que emergiram em torno da genética. Uma das suas dimensões de análise incidiu sobre as bases de dados de perfis de DNA para fins de investigação criminal, particularmente sobre os contextos científicos, técnicos, legislativos, sociais e de gestão 
da investigação criminal em vários países, os quais se encontram em distintas fases de desenvolvimento no que respeita às bases de dados de DNA com propósitos forenses.

3 A obra Genetic Suspects: Global governance of forensic DNA profiling and databasing, objecto desta recensão, é um livro bem sucedido, pois consegue ir além de uma mera colectânea de textos acerca dos usos das bases de dados de DNA de um ou vários países ou de uma descrição dos seus enquadramentos legais, ou, ainda, de uma monografia acerca das controvérsias e usos do DNA em contexto legal. Concretamente, propõe uma abordagem panorâmica de várias visões, perspectivas e dilemas acerca das tecnologias de DNA na contemporaneidade, ao mesmo tempo que integra um olhar histórico e geograficamente difuso sobre as tecnologias de identificação. 0 próprio título, Genetic Suspects: Global governance of forensic DNA profiling and databasing [Suspeitos genéticos: A governância global das bases de dados de perfis de DNA com propósitos forenses], proporciona o fi o condutor que engloba os objectivos do livro e que podem ser resumidos em várias questões, tais como, entre outras:

4 De que modo indivíduos e populações são "governados" pelas tecnologias que permitem a construção de perfi s de DNA e o seu armazenamento em bases de dados? Quais as formas e padrões de regulação e governância emergentes ao nível nacional e global? Que novas áreas de conflito surgiram e quem são os actores que protagonizam os debates? Quais são os principais desafios e impactos éticos, legais, sociais e culturais da implementação de bases de dados de DNA?

5 A ideia de "suspeitos genéticos" carrega em si um sentido histórico-simbólico que remonta à criminologia de Lombroso e à procura dos sinais de um "corpo criminoso" (Horn, 2003). Por outras palavras, se as tecnologias de identificação por perfis de DNA foram acolhidas e celebradas como um instrumento virtualmente infalível que permite estabelecer uma ligação entre um crime e o seu agente, o armazenamento de perfis genéticos em bases de dados veio trazer a possibilidade de monitorizar, agrupar e classificar indivíduos sem o seu consentimento, fazendo incidir o foco vigilante do Estado não apenas sobre os seus comportamentos, mas sobre a sua própria identidade biológica - o que pode significar que a vigilância também se estende aos seus familiares e, inclusive, às suas raízes étnicas (ver também Duster, 2006).

6 O público potencial deste livro é constituído por académicos, profissionais de justiça criminal e estudantes, mas também um público interessado nas questões contemporâneas da governância das bases de dados e dos usos dos perfis de DNA. Assim, mesmo que o leitor não seja advogado, juiz, procurador, técnico forense, biólogo molecular, agente da autoridade, ou mesmo habitual telespectador de séries de ficção, provavelmente já terá ouvido falar em ADN, ou DNA ${ }^{1}$, frequentemente em contextos associados a promessas de novas descobertas e importantes avanços científi cos. Apesar do vasto potencial e diversidade de aplicações nas áreas da biologia e da medicina, será possivelmente em termos de aplicação no domínio da justiça criminal que o DNA terá granjeado maior popularidade e familiaridade junto do público. Com efeito, desde meados da década de 80 do século XX que as análises de DNA têm sido aplicadas com sucesso à identifi cação de autores de crimes, bem como à eliminação de suspeitos e, inclusive, à exoneração de indivíduos condenados.

7 Como assinala Sheila Jasanoff no prefácio a esta obra, o sucesso do uso de perfis de DNA para fins de investigação criminal é uma história curta. Tudo começa em 1985 quando o geneticista Alec Jeffreys faz uma descoberta que viria a transformar o modo como hoje em dia se desenvolve a investigação criminal. Tratou-se da descoberta, quase por acaso, 
de regiões dos genes altamente variáveis de indivíduo para indivíduo que possibilitam uma identificação com elevado grau de certeza. A introdução de bases de dados de perfi s de DNA - a primeira foi implementada no Reino Unido (Inglaterra e País de Gales) em 1995 - veio permitir que as autoridades pudessem comparar perfis de DNA obtidos a partir de amostras de cenas de crime com os perfis inseridos na base de dados de forma rápida, automática e em larga escala, tendo esta prática vindo a ser disseminada um pouco por todo o mundo desde então.

Deste modo, é patente a relevância dos estudos em torno do estabelecimento e governância deste tipo de bases de dados. Hindmarsh e Prainsack reúnem um conjunto de contributos de vários autores de renome na área, com o objectivo de, conforme é referido no primeiro capítulo desta obra, "investigar os impactos e implicações para a governância de um dos mais bem sucedidos e controversos desenvolvimentos na história recente da ciência e da tecnologia: a introdução dos perfis e bases de dados de DNA no sistema de justiça criminal" (Capítulo 1: 1, tradução do autor).

Desde a sua implementação, as bases de dados de perfis de DNA têm vindo a ser apresentadas, quer pelos seus proponentes, quer nas representações mediáticas e ficcionais, numa perspectiva que enfatiza o seu potencial para o combate e prevenção do crime. Porém, à medida que se assiste ao crescimento e expansão dos usos deste tipo de tecnologia um pouco por todo o mundo, torna-se fundamental considerar as várias implicações sociais, éticas e políticas das bases de dados de perfis de DNA, na medida em que estas se situam numa encruzilhada na qual convergem preocupações relacionadas com os direitos civis, ciência e governância. Os editores deste volume definem a "governância" das bases de dados de DNA como o conjunto de regras, práticas, condutas e processos de decisão que se situam além dos instrumentos legislativos e governamentais.

10 Algumas destas preocupações são abordadas nos capítulos desta obra e incluem aspectos relacionados com a privacidade genética e a expansão da vigilância (aqui entendida como surveillance (Lyon, 2001)), a falta de harmonização das várias bases de dados de diferentes jurisdições, a fiabilidade das análises ao DNA e as interpretações ideológicas e científicas das provas de DNA, os potenciais erros e abusos associados à constituição de bases de dados, e preocupações com a segurança e/ou contaminação ligadas à recolha e análise de amostras biológicas, function creep², participação e confi ança pública na implementação e expansão de bases de dados, e as chamadas DNA dragnets ou análises de DNA em massa.

11 O livro encontra-se estruturado em duas secções distintas, mas que se complementam no sentido de a segunda proporcionar contextos e exemplos de casos de países onde se desenrolam actualmente dinâmicas e questões de governância das bases de dados de perfi s de DNA descritas na primeira.

12 A primeira secção, intitulada Key areas in DNA profi ling and databasing, incide sobre os principais aspectos e problemáticas associadas aos usos das bases de dados de perfis de DNA, na medida em que, conforme assinala Sheila Jasanoff no prefácio, descrevem "um complexo sistema tecnológico, composto de elementos e práticas sociais e materiais heterogéneas que suscitam problemas de governância ao mesmo tempo que prometem responder à questão 'quem é que cometeu o crime', sendo esta uma das principais preocupações em qualquer sociedade respeitadora da lei” (Prefácio: xxii, tradução do autor). 
13 A segunda secção deste livro intitula-se National contexts of forensic DNA technologies and key issues. Ao longo de nove capítulos, renomados especialistas de países como o Reino Unido, a Áustria, a Holanda, a Noruega, Portugal, os Estados Unidos da América, a Austrália, a Nova Zelândia e as Filipinas proporcionam reflexões sobre contextos e experiências de aplicação das tecnologias de DNA para fins forenses. Nesta secção, o principal ponto de interesse comum é a análise dos modos como a implementação e o desenvolvimento dos usos forenses das tecnologias de DNA são condicionados pelas contingências locais e respectivas tradições e culturas legais de cada país. Por exemplo, nos EUA, uma das principais problemáticas associadas à introdução das tecnologias de DNA tem que ver com disputas em torno da admissibilidade, em julgamento, deste tipo de prova, em parte devido à entrada em cena, desde cedo, de laboratórios privados, interessados na promoção dos seus produtos (Capítulo 12). Por seu turno, em países com sistemas de justiça criminal de cariz inquisitorial não é frequente verificar-se este tipo de polémicas, na medida em que, como refere Johanne Dahl no capítulo 10, os resultados dos exames são apresentados por "testemunhos periciais nomeados pelos tribunais" e, para além disso, tende a haver um monopólio estatal sobre os laboratórios que podem realizar análises de DNA admissíveis em tribunal.

Em suma, a segunda secção localiza as impressões globais da primeira secção no sentido de perspectivar de que modo diferentes jurisdições, culturas legais e estádios de desenvolvimento acolhem e implementam as tecnologias de DNA, e quais os desafios e dilemas que enfrentam na sua aplicação.

Para além de considerarmos este livro um excelente exemplo de cooperação académica internacional, o modo como os temas e exemplos são descritos e contextualizados possibilitam uma leitura acessível e interessante, inclusive para um público pouco familiarizado com os assuntos em discussão.

\section{BIBLIOGRAFIA}

DAHL, Johanne Y.; SÆTNAN, Anne R. (2009), “'It all happened so slowly' - On controlling function creep in forensic DNA databases”, International Journal of Law, Crime and Justice 37, 3, 83-103.

DUSTER, Troy (2006), “The molecular reinscription of race: Unanticipated issues in biotechnology and forensic science", Patterns of Prejudice, 40, 4-5, 427-441.

HENRIQUES, Fernanda e SEQUEIROS, Jorge (2007), Relatório - Regime jurídico da base de dados de perfis de ADN. Conselho Nacional de Ética para as Ciências da Vida. Disponível: http:// www.cnecv.pt/admin/files/data/docs/1285444328_Relatorio_base_dados_perfis_ADN.pdf [15 de Julho de 2011].

HORN, David (2003), The Criminal Body: Lombroso and the anatomy of deviance, London, Routledge. LYON, David (2001), Surveillance Society: Monitoring everyday life, Buckingham, Open University Press. 


\section{NOTAS}

1. Embora seja comum em português encontrar a sigla DNA (Deoxyribose Nucleic Acid) traduzida por ADN, que corresponde a ácido desoxirribonucleico, considera-se habitualmente que esta sigla não se deve traduzir e deve ser sempre utilizada a sua designação em inglês, ou seja, DNA (Henriques e Sequeiros, 2007: 5).

2. Numa tradução livre, function creep poderia designar-se por "usurpação de função", isto é, uma alteração ou função adicional ocorrida na aplicação de uma dada tecnologia (Dahl e Sætnan, 2009).

\section{AUTORES}

\section{FILIPE SANTOS}

Doutorando em Sociologia, Centro de Investigação em Ciências Sociais, Universidade do Minho,

filipesantos@ics.uminho.pt 